LAWRENCE A. REID (University of Hawai`i)

\title{
Seidenadel's Grammar of Bontoc Igorot: One Hundred Years On
}

\begin{abstract}
In 1909, Carl Wilhelm Seidenadel published a grammar, vocabulary and texts of a Philippine language that he called Bontoc Igorot. Although there are serious problems with his description of the phonology, his treatment of the syntax of the language was in some ways quite perspicacious. He was probably the first linguist to reject the traditional (at that time) treatment of the various transitive constructions of Philippine languages as passives, and offered an analysis that considered them to be active constructions. This chapter will review the work in the light of what is now known about the language, in particular his descriptions of the phonology and syntax, and relate his views to current issues in the typological characterization of the languages of the Philippines.
\end{abstract}

\section{Introduction}

In the early 1900's, several groups of men and women (more than ninety all told), were taken from their homes in various villages of Bontoc, presently the municipal capital of Mountain Province, to be displayed at the St. Louis World's Exposition in Missouri during the summer and autumn of 1906. In the autumn of 1906 the first group was joined by another contingent of about thirty men and women who had been scattered at different sites in the United States. During this period, and also in 1907, Carl Wilhelm Seidenadel (henceforth SDL), at one time, according to CONANT (1911) a member of the faculty of the University of Chicago in the Departments of Greek and Latin, met regularly with various members of the group in order to learn their language and describe it. Many of his language assistants had only a rudimentary knowledge of English, and SDL was forced therefore to gather his data monolingually. It was published in 1909, and is available on line, as The First Grammar of the Language Spoken by the Bontoc Igorot with Vocabulary and Texts. 592 pp. (Chicago: Open Court Publishing Co.)

Given the general view at that time of these loin clad, spear-carrying 'natives' who were put on display, somewhat like animals in a zoo, SDL's description of them is refreshing. He speaks of them as "these most sympathetic people, men of astonishing intelligence, inborn independence and frankness, strong principles of honesty, kind disposition, a vivid desire for learning, and blessed with the divine gift of healthy humor". He was less kindly disposed to those who had previously published studies of the language, as noted in CHAMBERLAIN's (1910) review of the work, “... he dismisses the Bontoc words in SAWYER's The Inhabitants of the Philippines (London, 1900) with the remark (p. 277), 'Sawyer's list is harmlessly incorrect'; of SCHADENBERG's vocabulary (Z. f. Ethno., 1889) he says that it 'is teeming with blunt errors'; and the section on language in JENKS's The Bontoc Igórot (Manila, 1905) gets praise for the vocabulary, but the grammatical notes are considered 'superficial' (p. xii)." Given the extensive errors in his own transcriptions and translations, he could have been a little more generous.

SDL's language assistants came from a number of dialectally distinct areas. He lists Gonogon, Alab, Samoki, and Tocucan, various towns along the main road going into and out of Bontoc town, as well as Bontoc town itself, each community speaking a distinct dialect. He also lists Sabangan, Basao, and Sagada, towns which were, at that time, part of Bontoc subprovince, but which today are subsumed as municipalities in Mountain Province. Their language is closely related to Bontok but is typically referred to as Kankanay or Kankanaey. He also mentions a town called Tagkong which I cannot identify. The home towns of some of his assistants are identified 
(e.g., Anauwasal from Tocucan, Agpauwan from Alab, and Matyu from Bontoc), however the spelling of the names of some of his assistants (Abakid, Bugti, Bumegda, Domingo, and Langagan) suggests that they came from one or another of the Kankanaey towns, since most of the towns of Bontoc [funtuk] municipality do not allow pre-vocalic voiced obstruents (see sec. 2.2 for discussion).

Considering the wide variety of dialects that SDL drew data from, and the fact that he apparently never visited the Philippines, his description is in some respects ground-breaking. This paper will review the work in the light of what is now known about the language, in particular his descriptions of the phonology and syntax, and relate his views to current issues in the typological characterization of the languages of the Philippines.

SDL was well aware of the considerable differences which existed between Bontok and the Indo-European languages with which he was familiar, but decided to retain for the convenience of students "the customary order of the chapters in [grammars of Indo-Germanic languages], if he would treat first the article, then the noun, pronoun, adjective, etc., just as if the Bontoc language would distinguish the same grammatical categories as the Indo-Germanic Languages" (xiii), but was careful to point out that "the sooner [the student] can free himself completely from clinging to his former notions of the structure of a language and adapt himself to new categories of linguistic elements, the earlier he will succeed in entering into the spirit of this admirable idiom" (ibid.). Throughout the grammar, SDL is concerned with describing how Bontok expresses concepts familiar to English speakers, such as "subject" and "object", but notes that he uses these terms "in our, but not the Igorot's conception!” (27).

\section{Phonology}

SDL was supremely confident of his ability to recognize and represent the sounds that he heard, and of his own erudition, frequently citing translation equivalents from Greek, Latin, Russian, French, Spanish, Scotch and German. In his words, "As all examples are recorded exactly as they were obtained from the Igorot, and as the men pronounced the same word in the same construction often with changed sounds and accents, it happens that some inconsistency prevails in orthography, accents and quantity. This is due to the natives' elocution, but not to the Author" (xiv). Unfortunately, every page of data is replete with misrepresentations, despite his claim that "Each word and phrase has been repeatedly verified by various single individuals, by small and larger groups of men and women, young and old, at different times and occasions, often employed unexpectedly in conversation, and special care was taken not to tire a man, as there is danger lest tired men answer so as to please the inquirer" (xiv). The generosity of his Bontok assistants, carefully noted by SDL, cannot be doubted. The following two sections will examine his treatment of the vowels and consonants, respectively.

\subsection{Vowels}

There are four phonemic vowels in Bontok, /i, u, i, a/ (see Table 1) (REID 1963, 2005). SDL established an alphabet of 13 vowels and 10 diphthongs for Bontok, based on the non-phonemic traditions of the time. Stress is contrastive, and is marked primarily by length on the vowels of open, penultimate syllables. A short open, penultimate syllable usually signals stress on the ultimate syllable. SDL correctly notes that some words differed only in vowel length, but incorrectly claims that vowel length and word accent can be located on different vowels in the same word (xiv). While also noting that a long vowel is sometimes only slightly longer than its short counterpart, he nevertheless incorrectly represents it in a large number of forms, e.g., fắto for [fă'tu] 'stone' (5), kó̄ko for [kŭ'ku] '(finger or toe) nail' (390), and alì́wid for [?ali'wid] 'friend 
(the kinship relation between the parents of spouses)' (66). ${ }^{1}$ One of the main problems with SDL's transcriptions, however, resulted from his inability to hear the unrounded central vowel which ranges from high to mid positions, and tends to be fronted before velars. In the Bontok broad phonetic examples to follow, the sound will be represented as [i] (or before velars as $[\varepsilon]$ ), although it is frequently identified in other works as schwa [ə]. SDL lists it among the vowels as $\ddot{o}$, "as in G[erman] könig, or F[rench] feu." He also notes that "final $\ddot{o}$ is frequently followed by a scarcely audible $y$ ", the latter combination being equivalent to one of his diphthongs, $\ddot{o y}$. He notes, " $e$ and $i$ are constantly interchanged; often $\ddot{o}$ is pronounced instead" (5). He also confused it with a. " $A$, which usually has a clear sound, is sometimes obscured, especially in unaccented syllables. In a few words initial $a$ is interchanged with $i$." One of the examples he gives is ăpắt vs ǐpắt 'four'. This form in all areas of Bontok and Kankanaey is [?i'pat]. Another example he cites, however, involves the prepositions is and id vs. as and ad (5). For these forms, the variation is real, but dialectal; some towns use one set, other towns use the other set and no central vowel is involved (Reid 2006).

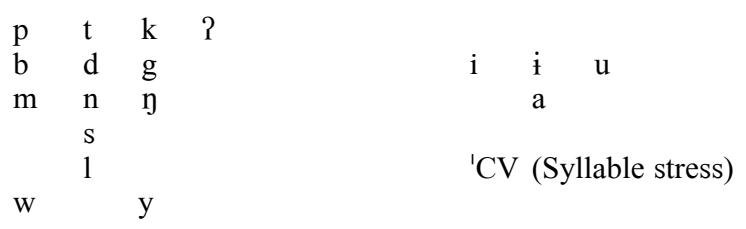

Table 1. Central Bontok Phonemic System in 1960 (from ReID 2005: 385)

\subsection{Consonants}

When SDL did his research, Bontok had fourteen consonantal phonemes, however within recent generations, a number of allophonic variants that have English equivalents have taken on phonemic status, primarily because of education in English, and borrowings from Ilokano and other Philippine languages (REID 1963, 2005) (see Table 2). He lists 17 consonants, “b, d, f, g, k, l, m, n, p, s, t, w, y, ng, sh, dj, tj". In addition, SDL notes that there is a "Glottal Check" in Bontok, stating that its occurrence is "strictly idiomatic; the words... in which it is employed can only be learned by observation.” When he heard it, he represented it with a slash (/), but did not list it as one of the consonants in the language. Generally however he didn't hear it (or didn't think it should be represented), and sometimes represented it where it doesn't occur, for example between a sequence of two identical letters, $n / n g$ for $n n g$ ([n]]), or geminate consonants (real or perceived), as in in/nîkid for [?in'ni:k+ ${ }^{\mathrm{h}}$ Id] /Pin'nigid/ 'left-handed' (376), papắt/tay for [pa'pattay] '(sacrificial) grove' (356), or kek/kek for [ $\mathrm{k}_{+}^{\mathrm{h} i \mathrm{t}} \mathrm{kek}$ ] /git'kik/ 'I know' (373). (For discussion of Bontok geminates, see AOYAMA \& REID 2006).

\begin{tabular}{|c|c|c|c|c|c|c|c|}
\hline $\mathrm{p}$ & $\mathrm{t}$ & & $\mathrm{k}$ & $?$ & & & \\
\hline f & & ts & $\mathrm{k}^{\mathrm{h}}$ & & & & \\
\hline $\mathrm{b}$ & d & & $\mathrm{g}^{+}$ & & $\mathrm{i}$ & $\dot{\mathbf{t}}$ & $\mathrm{u}$ \\
\hline \multirow[t]{4}{*}{$\mathrm{m}$} & $\mathrm{n}$ & & ฤ & & $\mathrm{e}$ & & o \\
\hline & $\begin{array}{l}S \\
1\end{array}$ & (s) & & $\mathrm{h}$ & & $\mathrm{a}$ & \\
\hline & $\mathrm{r}$ & & & & ${ }^{\prime} \mathrm{C}$ & Syl & le stress) \\
\hline & $\mathrm{y}$ & & & & & & \\
\hline
\end{tabular}

Table 2. Central Bontok Phonemic System in 2004 (from ReID 2005: 391)

Apart from glottal stop, there are three voiceless stops in Bontok, $/ \mathrm{p}, \mathrm{t}, \mathrm{k} /$, all unaspirated. None of them alternates in any position with a voiced stop. SDL correctly notes that $p$ and $t$ lack the following "spiritus asper" and that at the end of a syllable they (at least the alveolar and velar stops) are difficult to distinguish. He nevertheless commonly misrepresents them, especially at

\footnotetext{
${ }^{1}$ Where Seidenadel's definitions are mistaken, or inadequate, additional terms are added in parentheses, see REID (1976) and the revised on-line version of Talking Dictionary of Khinina-ang Bontok: The Language Spoken in Guinaang, Bontoc, Mountain Province, the Philippines (to appear, 2009).
} 
the end of a word as voiced $b$ and $d$ (because of his German background?), e.g., he represents ['Pa:nap] 'look for' as anab (with a b), but, [?a'na:pek] /Ra'napik/ 'I find (look for)' as anấpek (with $p$ in syllable-initial position). Likewise, ['Pi:kit] /'Rikit/ 'grandfather (grandparent)' is represented as íkǐd (12), and [fa'luknit] /ba'luknit/ 'battle' as fãlǒgnǐd (16). He also sometimes represents voiced consonants as voiceless, even at the end of a word, thus ['fo:tug] /'butug/ 'pig' is represented as fütuk (17), but elsewhere as fǘtug $(14,334)$. Although [p] and [t] do not alternate with their voiced counterparts, as claimed by SDL (8), voiced stops [b], [d], and [g] only occur postvocalically in Bontok dialects. Their prevocalic counterparts are respectively [f], [ts] and [ $\left.\mathrm{k}^{\mathrm{h}}\right]$. [ts] is a voiceless, alveolar affricate (SDL's $t j$ and $t s$ ), and in a few Bontoc towns, such as Mainit and Dalican, a voiced variant occurs, [c] (SDL's $d j$ and $d z$ ). [ $\left.\mathrm{k}^{\mathrm{h}}\right]$ is a voiceless, fronted, lightly aspirated velar stop. None of the Kankanaey towns have these variants (HIMES 1984-85) (see Figure 1).

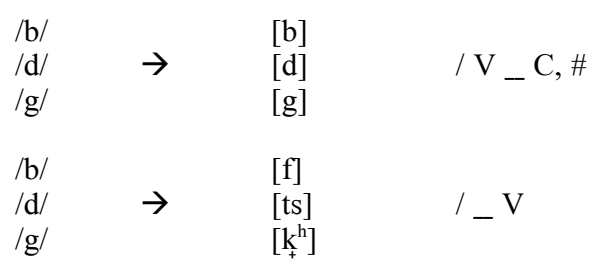

Figure 1. Central Bontok voiced stops (1960) (from REID 2005:387)

SDL's claim then that fắto and băto 'stone' exemplify $f$ and $b$ "interchange", while djî́la and díla 'tongue' exemplify $d j$ and $d$ "interchange", is not phonological variation; the first of each pair is restricted to Bontoc towns, the second to Kankanaey towns.

SDL did not hear the difference between the two voiceless velar stops, $\left[\mathrm{k}_{+}^{\mathrm{h}}\right]$ fronted and aspirated (the prevocalic variant of $/ \mathrm{g} /$ ), and $[\mathrm{k}]$ backed and unaspirated (the voiceless stop that contrasts phonemically with $/ g /$ ). It is only the latter, however, that he frequently represents as $g$, e.g., mangáfag for [ma'ya:fak] /ma'yabak/ 'to conquer' (317), while he always represents the former as $k$, e.g., mămăgkǐd for [ma'magk ${ }^{\mathrm{h}} \mathrm{It}$ ] /ma'maggit/ 'young girl (young unmarried woman)' (16). His example of $k$ and $g$ "interchange”, kinwânik and ginwānik for [kın'wa:nı] /kin'wanik/ 'I said', is neither an example of dialect (or language) variation, but of his inability to distinguish voiceless unaspirated stops from their voiced counterparts; there is no voiced velar stop in the word. The four variants that SDL provides for 'he makes' (5), kapếna, kapína, kapéna, kapöna—all of which represent [ $k_{+}^{\mathrm{h}} a b^{\prime}$ '?ina] (/gab'?ina/)—illustrate at least three of the problems discussed above, SDL's inability to distinguish the high, central vowel from other unrounded vowels, his inconsistency in marking glottal stops, and his tendency to misrepresent unaspirated voiceless and voiced stops.

The phoneme /s/ has two conditioned variants in Bontok. Adjacent to the high, front vowel /i/, Guinaang Bontok /s/ has an alveolar articulation point, similar to the pronunciation of $/ \mathrm{s} / \mathrm{in}$ Tagalog, Ilokano and many other Philippine languages, as well as English, as in Bontok [si'tso:k ${ }_{+}^{\mathrm{h}} \mathrm{an}$ ] /si'dugan/ 'water jar'. In other environments, /s/ is pronounced as a voiceless postalveolar apical central fricative [ș], i.e., in non-high front vowel environments, the body of the tongue is retracted, with the apex of the tongue pulled back to a post-alveolar position. This sound can also be described as a voiceless alveolar retroflexed grooved fricative [s]. SDL represents this variant of $/ \mathrm{s} /$ as $s h$ "as in shield". Although the sound is not palatal, as the English $s h$ representation suggests, it approximates the sound, and even today, some local orthographic representations of Bontok use $s h$ for this sound (REID 2005: 395). Thus, Sdl represents ['Ra:nis] /'Pajis/ as ấngash 'face (to breathe)' (336). 


\section{Syntax}

\subsection{Word Order}

Bontok word order is in many respects the same as in most other Philippine languages, with predicates, whether verb, noun or other word class occurring at the beginning of a sentence in unmarked constructions. Topicalized noun phrases occur before the predicate, either linked to it by a monosyllabic "particle", such as Bontok ya or ket, or by a break in intonation. "Auxiliary" verbs such as negatives precede lexical verbs and attract clitics. Copula verbs typically are not found.

SDL analyzed Bontok as having free word order "Substantives, demonstrative and indefinite Pronouns, Numerals, as subjects, either precede or follow the verb. If these subjects precede, the copula ya (for singular and plural and all tenses) is often placed between subject and verb; but never if the subject follows" (66). SDL treated personal pronouns differently (see sec. 3.4 below).

Large numbers of example sentences are included in the grammar, many of which (despite his claim that all his fieldwork was done monolingually) are clearly elicited via English, with the expected translation effect of copying English word order, as in ex. 1-2 (the first line is from SDL; the second is a phonetic representation; the third line provides the same sentence in the orthography of the language as commonly used today; the final line provides an English literal gloss):

(1) nan àmấma ya umiléngtja 'the old men are resting' (66)

[nan Ra'mam?a ya Pumil'?intsa]

nan amam-a, ya omil-engcha 'as for the old men, they are resting'

the old.men TOPLK rest $=3$ PL

(2) nan ongónga ya masúyep 'the child is sleeping' (66)

[nan Run?u'na ya masi'yip]

nan ong-onga, ya maseyep 'as for the child, it is sleeping'

the child TOPLK sleep

\subsection{Seidenadel's problem with "passives"}

SDL had a completely negative view of all descriptive work previously done on Philippine languages, claiming "It were best to consider the entire field of Philippine Languages as yet untouched and to begin anew to study [their languages] (but not without personal sympathy with the natives!)" (7). This view was based on his recognition, probably unique at the time, that what were claimed as "the three passives" in Philippine languages were, from his point-of-view, not passives at all. The following excerpts from the grammar summarize SDL's statements regarding this claim.

"The term "las tres pasivas" unfortunately invented some centuries ago by Spanish Grammarians for the three active conjugations in other Philippine languages (but not Bontoc Igórot!) must be rejected as erroneous... practically all Philippinists and Copyists of more or less obsolete Philippine Grammars are clinging to the wrong designation... (53)

"However convenient for minds trained, to some extent, in Latin the Doctrine of the Three Passives has appeared, centuries ago, to its inventor, and however credulously his disciples clung to this perverse interpretation of the Active Verbal Noun (Nom. actionis) in Tagalog and in the dialects of several other tribes - in the Bontoc Igorot Language the Verbal Noun is certainly not passive, but active in its character...

"The fact that the Three Passives Fallacy has been propagated in good faith for two centuries and is still indefatigably copied and republished and taught, show (as also other factors do) how necessary it is to revise and to compare the "Artes" of time-honored "authorities" and the entire material of sacred books, catechisms, confessionals, prayer books, with the living dialects spoken by the natives. The result of such future careful investigations 
into the people's vernacular, the collection of tales and songs in the unbiased dialects of the different tribes ought to be most welcome to Comparative Philologists who seem to rely only on the unreliable material at hand, faute de mieux, material collected by unphilological compilers, with a few admirable exceptions, such as TOTANES, [and] MinGUELLA.

"The unfelicitous term of the Three Passives (which may have sprung from its originator's inability to distinguish between the Gerundium and Gerundivum) was employed unscrupulously in many grammars and learned articles and papers on various Philippine dialects; Bontoc Igorot excepted.”2 (71-72)

SDL then cites (with page references) some twenty-five (mainly Spanish) publications on Philippine languages that he apparently had access to, in which "the Three Passives and their alleged applications occur" (72). These range from the Spanish grammars of Ilokano by FRANCISCO LOPEZ (1628) and of Tagalog by SEBASTIAN DE TOTANES (1796) to those of Hiligaynon by ALONSO MENTRIDA (1818), of Ibanag by JOSÉ MARIA FAUSTO DE CUEVAS (1854), of Maguindanao by JACINTO JUANMARTI (1892), and numerous other works by scholars such as BRANDSTETTER and KERN which appeared toward the end of the 19th and the early 20th centuries. Such early works were also probably available to VAN DER TUUK, who referred to the three passive constructions of Toba Batak in Sumatra (VAN DER TUUK 1971 [1864-67]), characterizing them as "substantives", and also to ADRIANI who similarly claimed in his description of Sangir, the Philippine-type language spoken in Sulawesi (ADRIANI 1893), "The active and passive forms in Sangir are sharply distinguished. The active, as has already often been noted, is actually the only verbal form, the passive is a noun, and the imperative likewise; the distinction between active and passive in the latter is observed only in speech" (translated and cited by BLUST 2002: 64).

In order to put these comments into context, the following is a set of data from the dialect of Bontoc spoken in the Guina-ang community, referred to locally as Khinina-ang. Each of the examples is a simple declarative construction, although with appropriate intonation each could function as an imperative. The actor pronoun in all examples is obligatory, unless recoverable from context. ${ }^{3}$ SDL calls all such constructions "active”. REID \& LIAO (2004: 453) refer to them as "dynamic". ${ }^{4}$ Only constructions patterning like ex. 3-4, in which the actor is the grammatical subject, were labeled "active" in early descriptions. Constructions patterning like ex. 5-7, in which the actor has a genitive case form and the other noun phrase (the grammatical subject) expresses an undergoer of some sort, were labeled as "passive". 5

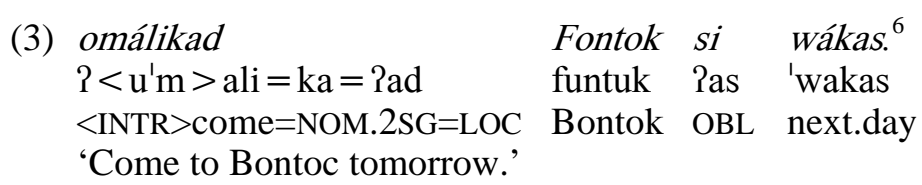

\footnotetext{
${ }^{2}$ Gerundium: "In Latin, a verbal noun used in all cases but the nominative.” Gerundivum: “A Latin verbal adjective, with a typical gerund stem form, used as a future passive participle expressing duty, necessity, fitness, etc.” Webster's New Twentieth Century Dictionary (Unabridged).

${ }^{3}$ This is not only true for Bontok, it is also true for similar constructions in other Philippine languages, such as Cebuano (PAYNE 1994, TANANGKINGSING \& HUANG 2007).

${ }^{4}$ The Appendix contains the same set of data (with corresponding numbers) showing how each sentence would have been analyzed by SDL.

${ }^{5}$ Glossing and abbreviations follow the Leipzig Glossing Rules. The first line of each is example is given using a local orthography. The second line provides a phonemic transcription, showing verbal affixation and basic forms of verbs and pronominal clitics. It also brackets and labels phrases that are (morphologically) unmarked for case. The third line provides a literal translation for each form and the fourth line is a free translation. Other abbreviations are: DFCT direct affect; LFCT locative affect; MFCT manner affect (sometimes referred to as voice-marking affixes); and TOPLK topic linker.

${ }^{6}$ The oblique preposition / Ras/ has a variant/si/ following words ending in a consonant. Following words ending in a vowel, it is typically reduced to $/=\mathrm{s} /$, as in ex. 4 . The full form occurs in deliberate speech, and in sentence initial position.
} 
(4) omárakas

fótog.

$?<\mathrm{u}^{\prime} \mathrm{m}>$ ara $=\mathrm{ka}=\mathrm{Pas} \quad$ 'futug

$<$ INTR $>$ get $=$ NOM.2SG=OBL pig

'Get a/some pigs.'

(5) ará-em nan fótog.

Pa'ra-?in $=m u \quad\left[\begin{array}{ll}\text { nan } & \text { 'futug }\end{array}\right]_{\text {Nom }}$

get-DFCT $=$ GEN.2SG SPEC pig

'Get the pig.'

(6) charosam nan áfong.

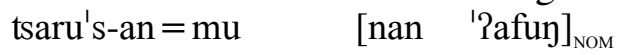

clean-LFCT=GEN.2SG SPEC house

'Clean the house.'

(7) iyálim nan fótog.

Pi-'Pali $=m u \quad[\text { nan 'futug }]_{\text {NoM }}$

MFCT-come $=$ GEN.2SG SPEC pig

'Bring the pig.'

Various overviews of the history of terminology in the description of Philippine languages have appeared, including FRENCH (1987-1988), HIMMELMANN (2002), ROSS (2002) and BLUST (2002). The use of the term "passives" to characterize those constructions in Philippine languages in which the grammatical subject (variously referred to in some works as the topic, trigger, or pivot) expresses some role other than the actor, continued to be used by the American linguists BLAKE (1904, 1905, 1906b, 1906a, 1917, 1925) and BLOOMFIELD $(1917,1942)$ in their descriptions of Tagalog, Bisayan and Ilokano, and subsequently by various other linguists, such as GIVón (1979), BELL (1976, 1983) in her description of Cebuano, and WOLFF (1996:17) in his reconstruction of Proto-Austronesian "active and three passive" verbal affixes. Linguists belonging to the Summer Institute of Linguistics in the Philippines, beginning around 1955, recognizing the inapplicability of the term passive for these constructions, began using the term "focus" instead, which as noted by HIMMELMANN (2002:14) only served to contribute to the confusion in terminology. He warned, nevertheless, that one shouldn't be confused by the "passive" terminology, noting that most authors, including Bloomfield, were well aware that the change in voice, that is the change from "active" to "passive" didn't affect the transitivity of the overall construction (HIMMELMANN 2002:14). But this statement is controversial, as many linguists have claimed that it is only the "passive" constructions that are transitive and that the "active" constructions are all intransitive (see section 4.2).

The fact remains however, that the structures in question typically do not meet two of the prototypical minimal conditions for being labeled as passive (SHIBATANI 1985, COMRIE 1988), namely: 1) the defocusing of agents, and 2) markedness, or relatively low text frequency relative to active constructions. SDL was correct in claiming that all such constructions are "active", although referring to them as "active conjugations" incorrectly suggests that there is an inflectional relationship among them. The so-called "voice-marking affixes" which occur on the verbs are not inflectional but derivational, ${ }^{7}$ in that they cannot freely occur on all verbs, do not freely commute with one another as in a voice-marking system, and are typically maintained in nominalizations and other derivational processes (REID \& LIAO 2004:453). SDL notes that these affixes ("particles") transform a root into an active verbal form, and indicate that that action

\footnotetext{
${ }^{7}$ In the analysis that is followed here, the "voice-marking” affixes are considered to be phonological sequences that indicate that the verb carries an "affect" feature. A DIRECT AFFECT feature indicates that the undergoer is directly or fully affected by the action. A LOCATION AFFECT feature indicates that the undergoer is only surface affected, or is the location of the action. A MANNER AFFECT feature indicates that the undergoer is a concomitant, or is physically transported or otherwise moved through space by the action. Affixes marking a BENEFACTIVE AFFECT feature, distinct from those listed here, is also found in Bontok and is discussed by SDL. He was fully aware of the semantic effects of these affixes and described them in detail.
} 
named by the root passes from the agent to an object. They give the active verbal form transitive force (70).

SDL was also correct in noting that for each of the active transitive constructions there is a corresponding intransitive construction which can be considered to be passive (71, 93-97). Thus, corresponding to ex. 5-7 above, constructions such as ex. 8-10 are found in which agents are obligatorily absent. REID \& LIAO (2004:453) refer to them as "stative", although other linguists call them "passive" (TANANGKINGSING \& HUANG 2007).

$\begin{array}{ll}\text { (8) na-ára } & \text { nan fótog. } \\ \text { na-'Para } & \text { [nan 'futug }]_{\mathrm{NOM}} \\ \text { PRF.STTV-get.DFCT } & \text { SPEC } \text { pig }^{8} \\ \text { 'The pig was gotten.' } & \\ \text { (9) nacharosan } & \text { nan áfong. } \\ \text { na-tsaru's-an } & \text { [nan 'Pafun }]_{\mathrm{NOM}} \\ \text { PRF.STTV-clean-LFCT } & \text { SPEC house }\end{array}$

'The house was cleaned.'

$\begin{array}{lll}\text { na-iyáli } & \text { nan } & \text { fótog. } \\ \text { na-Pi-'?ali } & {[\text { nan }} & \text { 'futug }]_{\text {NOM }} \\ \text { PRF.STTV-MFCT-come } & \text { SPEC } & \text { pig } \\ \text { 'The pig was brought.' } & \end{array}$

\subsection{Seidenadel's verb classification}

SDL divides verbs (in "active declarative main sentences") into two major types: a) "personal verbs" and b) "possessive verbs" (52). The former are the equivalent of what in later descriptions would be called "actor focus". The latter are the equivalent of "non-actor focus" verbs. SDL labels the former as "personal" because he treats all pronominal endings, now recognized as nominative clitic pronouns, as inflectional endings on the verb. Without the personal ending (as when a nonpronominal substantive occurs as the grammatical subject) he says the verbs of this category are most similar to our participles or verbal adjectives (51). He says that the term "intransitive" which would be quite appropriate for many verbs of this category (as ex. 3 above) "would be misleading, as many of them are used also as transitives, though with less transitive force than the verbs of the class b" (as ex. 4 above). He correctly notes that such verbs "have more stress on the verb than on a definite object, the object being indefinite or general or taken in a partitive sense" (54). He also notes that such verbs, although transitive have no corresponding passive construction. The transitivity of verbs of this class continues to be argued in the literature, with some claiming that while such verbs carry semantic transitivity, their affixation typically matches clearly intransitive verbs, and the sentences they head are syntactically intransitive antipassive constructions, with downgraded undergoers, case-marked (when expressed) by either oblique (as in Bontok), or genitive or locative (as in Tagalog) prepositions. Of the class b verbs, SDL similarly considers all these forms to be "nomina actionis" (active) verbal nouns, to which the "possessive suffixes are agglutinated to distinguish the person of the agent" (36). He claims that "Possessive suffixesequivalent to the possessive genitive of the personal pronouns-are employed in Bontoc Igorot, instead of our possessive pronouns" (34).

SDL was confronted with the problem of trying to describe the syntax of what are clearly transitive sentences in an ergative system from the viewpoint of someone who was apparently only familiar with accusative languages. This forced him into several problematic analyses, particularly with his description of the pronouns of the language. The following section will provide a brief overview of the way pronouns are currently understood to function in the language as a basis for understanding the analyses that SDL provided.

\footnotetext{
${ }^{8}$ There is no overt marking for the "direct affect” feature, when the verb carries the perfective infix $<$ in $>$.
} 


\subsection{Pronouns}

There are three sets of pronouns in Bontok (see Table 3). Two of the sets are enclitic to the verb; one is nominative (or absolutive) ${ }^{9}$ and functions as the $\mathrm{S}$ of an intransitive sentence (as in ex. $11) ;{ }^{10}$ the other is genitive (or ergative) and functions as the $\mathrm{A}$ of a transitive sentence or as the possessor of a possessed noun (as in ex. 12). The third set consists of independent forms that are not case marked. They can function without any additional marking as the $\mathrm{P}$ of a transitive sentence (as in ex. 13), as a fronted, topicalized S or A (as in ex. 14-15), or as the nominal predicate of a sentence (as in ex. 16). They can also be preceded by a personal oblique-marking preposition to function as dative pronouns (as in ex. 17).

\begin{tabular}{|l|l|l|l|}
\hline & Unmarked & Nominative & Genitive \\
\hline 1SG & sak-en & $=\mathrm{ak}$ & $=\mathrm{ku},=\mathrm{k}$ \\
\hline 2SG & sik-a & $=\mathrm{ka}$ & $=\mathrm{mu},=\mathrm{m}$ \\
\hline 3SG & siya & $\varnothing$ & $=\mathrm{na}$ \\
\hline 1DL & cha-ita & $=\mathrm{ta}$ & $=\mathrm{ta}$ \\
\hline 1PL.EXCL & chakami & $=\mathrm{kami}$ & $=\mathrm{mi}$ \\
\hline 1PL.INCL & chataku & $=$ taku & $=\mathrm{taku}$ \\
\hline 2PL & chakayu & $=\mathrm{kayu}$ & $=\mathrm{yu}$ \\
\hline 3PL & cha-icha & $=$ cha & $=\mathrm{cha}$ \\
\hline
\end{tabular}

Table 3. Guinaang Bontok Personal Pronouns

$$
\begin{array}{lll}
\text { inméyak } & \text { ad } & \text { Fontok. } \\
\mathrm{P}<\text { in }><\mathrm{u}^{\prime} \mathrm{m}>\text { iy }=\text { ak } & \text { ad } & \text { funtuk } \\
<\text { PRF }><\text { INTR }>\text { go=NOM.1SG } & \text { LOC } & \text { Bontoc } \\
\text { 'I went to Bontoc.' } & &
\end{array}
$$

$$
\begin{aligned}
& \text { inneyko nan fótogko. } \\
& \mathrm{i}<\mathrm{in}><\mathrm{i}^{\prime} \mathrm{n}>\text { iy }=\mathrm{ku} \quad[\text { nan } \quad \text { 'futug }=\mathrm{ku}]_{\text {NoM }_{1}} \\
& <\text { PRF }><\text { MFCT }>\text { go }=\text { GEN.1SG SPEC pig }=\text { GEN.1SG }
\end{aligned}
$$

'I took my pig.'

(13) inílam

$$
\text { sak-en. }
$$

$?<\mathrm{i}^{\prime} \mathrm{n}>\mathrm{ila}=\mathrm{mu}$

$<$ PRF $>$ Saw.DFCT=GEN.2SG 1 SG

'You saw me.'

$$
\begin{array}{lll}
\text { sak-en, } & \text { (ya) } & \text { inméyak. } \\
\text { [sak?in }]_{\text {TOP }} & \text { ya } & 1<\text { in }><\mathrm{u}^{\prime} \mathrm{m}>\text { iy }=\mathrm{ak} \\
\text { 1SG } & \text { TOPLK } & <\mathrm{PRF}><\mathrm{INTR}>\text { go }=\text { NOM.1SG } \\
\text { 'As for me, I went.' }
\end{array}
$$

$$
\begin{array}{lllll}
\text { sak-en, } & \text { (ya) } & \text { inneyko } & \text { nan } & \text { fótogko. } \\
\text { [sak?in }]_{\text {TOP }} & \text { ya } & 1<\mathrm{in}><\mathrm{i}^{\prime} \mathrm{n}>\mathrm{iy}=\mathrm{ku} & \text { [nan } & \text { 'futug }=\mathrm{ku}]_{\text {NOM }} \\
\text { 1SG } & \text { TOPLK }<\mathrm{PRF}><\mathrm{MFCT}>\text { took=GEN.1SG } & \text { SPEC } & \text { pig=GEN.1SG } \\
\text { 'As for me, I took your pig.' } & &
\end{array}
$$

\footnotetext{
${ }^{9}$ Although Bontok is an ergative language (an analysis not without controversy), as are many other Philippine languages (LIAO 2004), the term nominative is retained as the case of the grammatical subject, for a number of reasons, among which are: a) the syntactic features of an absolutive NP in an ergative language are typically no different from those of a nominative NP in an accusative language, and b) the term nominative has survived from earlier analyses, such as that by SDL, and is commonly used in descriptions of "Philippine-type languages" in the Philippines and elsewhere, regardless of the analyst's view as to the case-alignment of the language.

${ }^{10}$ Relevant forms in the examples appear in bold font.

${ }^{11}$ The "manner affect" feature on the Guina-ang Bontok verb 'go', infix $/<$ in $>/$, is irregular. In other communities this verb carries the regular marking for "manner affect”, prefix /Ri-/, as occurs also on the verb 'come' in ex. 10 and 17.
} 
(16)
sak-en nan nangney nan fótogmo.
$[\text { sakitn }]_{\text {PRED }}[\text { nan nay-?<i'n }>\text { iy } \quad \text { las nan 'futug }=m u]_{\text {NOM }}$
1SG SPEC PRF.NMLZ- $<$ MFCT $>$ go OBL SPEC pig=GEN.2SG
'I was the one who took your pig.' (Lit. 'The taker of your pig was me.')

$\begin{array}{lllll}\text { iyálim } & \text { nan } & \text { fotog } & \text { an } & \text { sak-en. } \\ \text { Pi-'Pali = mu } & {[\text { nan }} & \text { 'futug }]_{\text {NoM }} & \text { Pan } & \text { sak?in } \\ \text { MFCT-come=GEN.2SG, } & \text { SPEC } & \text { pig } & \text { OBL } & \text { 1SG } \\ \text { 'Bring the pig to me.' } & & & & \end{array}$

The only forms that SDL considered to be true pronouns were the unmarked forms, noting also that shortened forms of the pronouns were attached as personal agreement suffixes on "personal verbs". He considered the unmarked forms to be nominative and was forced to conclude, because the same form was used for the undergoer of a "possessive verb", that "The form of the personal pronoun for nominative and accusative is alike in Igorot" (30). SDL considered the subjects of his "personal verbs" to be in the nominative case, but not the agents of his "possessive verbs" (65). The pronominal endings of such verbs were considered to be suffixed agreement markers, not pronouns (although he likens them to the "pronominal subject of our 'transitive' verbs" (36). This analysis was supported by the fact that the forms are in fact phonologically attached to the verb, and by his view that transitive verbs are not really verbs at all, but nouns, and therefore the agreement forms were genitive and different from those that appeared on intransitive verbs. SDL's analysis suggests that even third person substantives would also be marked on the verb, as, for example, in Chamorro (TOPPING 1973:106, COOREMAN 1988:565, REID 2002:70), but typically they are not.

In order to consider the independent, unmarked pronouns as the grammatical subject of intransitive verbs, SDL needed to analyze the optional topic linker ya in sentences such as ex. 14 and 15 as a copula, giving a possible SV word order. "If these subjects precede, the copula ya (for singular and plural and all tenses) is often placed between the subject and the verb; but never if the subject follows" $(15,66)$. He recognized however that personal pronouns in sentences with this word order were focused, and therefore "[t]he personal pronouns, as subjects of verbs, are only used to emphasize the subject."

SDL's view that unmarked pronouns are used for emphasis fitted neatly into his analysis of the difference between the various transitive sentences, in which "accusative" NPs, when pronouns, were "emphatic". He states, "Personal pronouns, used only if the subject shall be emphasized, precede the verb" (66). Similarly, "If emphasized, place, cause, instrument, time, the indirect object or dative, etc., can be made the subject ... of peculiar verbal forms" (27). This is little different from the views of Blake and later linguists who considered that the "subject" or "focused item" functioned to emphasize that NP.

While considering the undergoer of a transitive verb to be "accusatively marked", he nevertheless clearly recognized that such NPs don't correspond to the accusative NPs of English. In introducing the verbs that head transitive sentences, he said, “...by employing special verbal forms the person in whose behalf, for whom an action is performed, or the instrument used in the action, or the place, time, cause, where, when, why the action takes place, took, will take place, can be made the "subject" or "object" as we would say" (italics provided) (89). Similarly, in discussing the position of "[the] "subject" and "object" [of transitive verbs]", he notes that "verbs which we consider customarily [to be] transitive... are of a completely different nature in Bontoc Igorot" (25).

SDL considered what we refer to today as cleft constructions as constructions which emphasize one of the nominals in a sentence, as illustrated in ex. 16. He says, "Thus while some stress is laid upon the elements treated as "subjects" or objects", stronger emphasis is expressed by placing the important substantive or pronoun etc. at the beginning of a sentence, followed by nan and the Nomen actionis" (92). Similarly, "The "Accusative Object" as we should say, is strongly emphasized by being placed at the beginning of a sentence, followed by the Nomen actionis with its endings" (100). 


\subsection{Other verbal categories}

\subsubsection{Voice, Tense and Mood}

As noted above, SDL analyzed Bontok as having both active and passive voice, with both personal verbs and possessive verbs having active voice, but only possessive verbs able to appear in passive voice. The active constructions, he says, are much preferred to the passive (53). In this analysis he foreshadows analyses of Philippine languages that have appeared only relatively recently.

Verb forms in Bontok have only two tense-aspect forms, one which is basically unmarked, which is used as the infinitive and also for actions that are non-completed, including past, present, on-going, and future actions, and the other marking perfective aspect for actions that are, have been or will be completed at some specified point in time relative to the present.

According to SDL, Bontok has three tenses, present, preterite and future. The present is unmarked. The preterite, he says, is marked by "the particle in-" which he then labels an "augment" to distinguish it from the "prefix in- of some personal verbs" (60). This analysis reflects SDL's inability to hear, or recognize glottal stop as a consonant, since the so-called "augment" is actually an infix, although with glottal stop initial forms, it may be heard as a prefix. The "prefix in- of some personal verbs" is a true prefix, and the initial glottal stop of a word is always retained after the, prefix. Thus Bontok /Rin-Pu'dan/ [?in?u'tsan] in-ochan 'to rain' is represented by SDL as inùtjăn (with a prefix and no indication of the glottal stop that follows it, and incorrect stress) (61), while the preterite form of a possessive verb that begins with a glottal stop is shown in the same way. Thus $/ 2<\mathrm{in}>\mathrm{a}$ yag-a-k/ [?ina'ya: $\mathrm{k}^{\mathrm{h}} \mathrm{ak}$ ] inayákhak 'I called' is represented by SDL as inayákak (78). SDL recognized the "augment" as an infix when "it is placed between the initial consonant and the following vowel of verbs beginning with a consonant" but seemed surprised that an affricate is treated as a single segment in the phonology, giving an example tsinúblak 'I smoked', with the comment “[ts] is taken as one consonant!"

Other ways of marking the perfective form of verbs, such as nin-, na- and nang- that correspond to the unmarked affixes in-, ma- and mang- respectively are correctly identified.

SDL claims that future tense is marked by "the prefix $a d$ - [at-]" preceding the forms of the present. The form is actually /at/, ${ }^{12}$ no voicing is involved, and it is not a prefix but an adverbial form precliticized to the verb, or to other adverbials forms which intervene between it and the verb, as in Sdl’s adtsádlo fumắngŏnak. for at chadlo fomángonak "I shall indeed awake”.

Following the outline of grammars of European languages, SDL identified two moods in Bontok... indicative and imperative, although typically the only feature that distinguishes the two is intonation (62).

\section{Conclusion}

SDL's grammar of Bontoc is supplemented by a "Vocabulary", actually an English to Bontoc finder list of approximately 2000 English entries, and by about 100 pages of interlinear texts, "the only Bontoc Igorot texts in existence" at that time. (A considerable number of text materials from various dialects are now available, see REID 1992 and KIKUSAWA \& REID 2003). SDL's texts (with their explanatory notes) are probably the most valuable part of the whole work although flawed by the problems of incorrect transcription discussed in the section above on phonology. Work is in progress to re-transcribe the texts (with corrections of inadequate translations) to increase the value of the work.

The major value of the grammatical section of the work is its recognition of the true nature of the so-called "passive" constructions as the main transitive structures in the language, perhaps

\footnotetext{
${ }^{12}$ In Guina-ang Bontok, the equivalent form is / Ras/.
} 
one of the first of the post-Spanish tradition grammarians to do so, and certainly foreshadowing work that was not to appear for another fifty or so years.

The major problems with the work are first its inadequate transcriptions, which completely obscure the patterned phonological alternations that exist in the language, brought about not only by SDL's inability to distinguish between voiceless unaspirated and voiced stops and the consonantal significance of glottal stop, but also by his mixing of forms from dialects that have different phonological rules. The other major problem lies in its form of presentation, which follows that of a European grammar, and required that distinctions which exist in such languages be the basis for the description of Bontok, even though SDL was well-aware of the inadequacies of the system for describing the grammar of a language which was so different.

SDL's view of the nominal nature of the syntax of Bontok, specifically his claim that transitive verbs appear to be nouns in that their actors are expressed by "genitive" forms that are identical to the possessors of nouns in noun phrases was certainly not new then (it had been claimed at least by VAN DER TUUK and by ADRIANI (as cited above) in the nineteenth century, and was no doubt a common claim among Spanish grammarians as well, and continued to be a staple of grammarians who have published on Philippine-type languages throughout the twentieth century, for example NAYLOR (1995:162), who writes: "The syntax of Tagalog predications is based on nominal relations rather than verbal relations and the type of predication is attributive rather than predicational. This is because the verbal word, as LOPEZ $(1928,1941)$ pointed out, is not a 'real verb' but only a 'quasi-verb'; Tagalog 'verbs' are in fact nomina actionis....” (See also NAYLOR 1979, 1999, 2001, 2005; DE WOLF 1988, 1979; HiMMELMANN 1991, etc.) ${ }^{13}$

It has long been recognized that the syntax of languages as spoken today is an amalgam of the ebb and flow of individual changes in the history of their phonology and morphology, often characterized as "grammaticalization", which introduce irregularities and ultimately result in systematic restructuring. These are also the processes which have brought about the current systems in so-called Philippine-type languages, of which Bontok is an example. In a paper published some twenty-five years ago on the development of the "focus system" in Austronesian languages, STAROSTA et al. (1982) claimed that the verb forms of today's transitive constructions were in fact nominal derivations in Proto-Austronesian, but subsequently developed as verbs when occurring as predicates. Others (WOLFF 1973, 1979, 1996; Ross 1995) have claimed that already by Proto-Austronesian the forms were functioning as verbs in the language.

Finally, it should be noted that in the absence of any other substantial grammar of the language (but see REID 1965, 1970), the editors of the online World Atlas of Language Structures (http://wals.info/index) have mined SDL for facts about the language, referencing it for seventeen typological features. Among those listed which need revision (simply because SDL was mistaken, often basing his claims on English translation equivalents, and not only because there are questions about what constitutes a "subject" or an "object" in an ergative language), are Features 81 and 82, which list it among languages which have no dominant order for either subject, object and verb, or for subject and verb. Bontok is clearly a language that has initial verbs in unmarked constructions and agents ("subjects") typically precede undergoers (“objects"), making it a "VSO" language.

\section{References}

ADRIANI, N. 1893: Sangireesche spraachkunst. Leiden: A.H. Adriani.

Aoyama, Katsura \& Lawrence A. Reid 2006: Cross-linguistic tendencies and durational contrasts in geminate consonants: An examination of Guinaang Bontok geminates. Journal of the International Phonetics Association 36.2, 145-157.

Bell, SARAH J. 1976: Cebuano subjects in two frameworks. Ph.D. dissertation, Massachusetts Institute of Technology. Bell, Sarah J. 1983: Advancements and ascensions in Cebuano, in: PerlmutTer, David (ed.), Studies in relational grammar I, Chicago: University of Chicago Press, 143-218.

\footnotetext{
${ }^{13}$ I wish to thank Hsiu-chuan Liao for providing some of the references in this section.
} 
Blake, Frank R. 1904: Differences between Tagalog and Bisayan. Journal of the American Oriental Society 25, 162169.

Blake, Frank R. 1905: The Bisayan dialects. Journal of the American Oriental Society 26, 120-136.

BLAKE, FRANK R. 1906a: Contributions to comparative Philippine grammar. Journal of the American Oriental Society 27, 317-396.

Blake, Frank R. 1906b: Expression of case by the verb in Tagalog. Journal of the American Oriental Society 27, 183189.

BLAKE, FrANK R. 1917: The Tagalog verb. Journal of the American Oriental Society 37, 396-414.

BLAKE, FRANK R. 1925: A grammar of the Tagalog language: The chief native idiom of the Philippine Islands. New Haven: American Oriental Society.

BLOOMFIELD, LEONARD 1917: Tagalog texts with grammatical analysis. University of Illinois Studies in Language and Literature - vol. III. Urbana: University of Illinois.

BlOOMFIELD, LEONARD 1942: Outline of Ilocano syntax. Language 18, 193-200.

BLust, ROBERT 2002: Notes on the history of focus in Austronesian languages. in: Wouk, FAy \& Ross, MALCOLM (eds.), The history and typology of Western Austronesian voice systems. Canberra: Pacific Linguistics, Australia National University, 63-78.

Chamberlain, Alexander F. 1910: Review of: The First Grammar of the Language Spoken by the Bontoc Igórot, with a Vocabulary and Texts, Mythology, Folk-Lore, Historical Episodes, Songs by Carl Wilhelm Seidenadel. American Anthropologist, New Series 12.2: 321-323.

Comrie, Bernard 1988: Passive and voice, in: Shibatani, Masayoshi (ed.), Passive and voice, Typological Studies in Language - vol. 16. Amsterdam/Philadelphia: John Benjamins, 9-23.

Conant, CARlos E. 1911: Review of: The First Grammar of the Language Spoken by the Bontoc Igorot, with a Vocabulary and Texts, Mythology, Folk-Lore, Historical Episodes, Songs by Carl Wilhelm Seidenadel. Classical Philology 6.3: 365-367.

Cooreman, Ann. 1988: The antipassive in Chamorro: Variations on the theme of transitivity, in: SHIBATANI, Masayoshi, Passive and voice, Typological Studies in Language - vol. 16. Amsterdam/Philadelphia: John Benjamins, 561-593

De Wolf, Charles M. 1979: Sentential predicates: A cross-linguistic analysis. Ph.D. dissertation, University of Hawai'i.

De Wolf, Charles M. 1988. Voice in Austronesian languages of Philippine type: Passive, ergative, or neither? In: Typological Studies in Language - vol. 16. Amsterdam/Philadelphia: John Benjamins.

French, Koleen Matsuda 1987-1988: The focus system in Philippine languages: A historical overview. Philippine Journal of Linguistics 18-19, 1-27.

GIVón, T. 1979: On understanding grammar. New York: Academic Press.

Himes, Ronald S. 1984-85: Allophonic variation and the Bontok-Kankanaey voiced stops. Philippine Journal of Linguistics 15-16:49-56.

Himmelmann, Nikolaus P. 1991: The Philippine challenge to Universal Grammar. Arbeitspapier Nr. 15 (Neue Folge): Institut für Sprach Wissenschaft, Universität zu Köln.

HimmelmanN, Nikolaus P. 2002. Voice in western Austronesian: An update. in: Wouk, Fay \& Ross, Malcolm (eds.), The history and typology of western Austronesian voice systems. Canberra: Pacific Linguistics, 7-16.

KIKUSAWA, RiTSUKO \& LAWRENCE A. REID 2003: A Talubin text with wordlist and grammatical notes. Journal of Asian and African Studies 65, 89-148.

LiaO, Hsiu-Chuan 2004: Transitivity and ergativity in Formosan and Philippine languages. Ph.D. dissertation, University of Hawai i.

LOPEZ, CECILIO 1928: Comparison of Tagalog and Iloko. Hamburg: J. J. Augustin.

LOPEZ, CECILIO 1941: A manual of the Tagalog language. Manila: Institute of National Language.

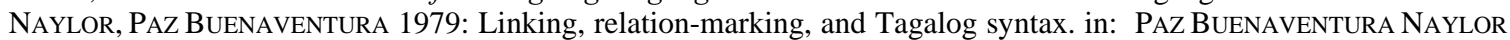
(ed.), Austronesian studies: Papers from the Second Eastern Conference on Austronesian Languages. Ann Arbor: Center for South and Southeast Asian Studies, University of Michigan, 33-50.

NAYloR, PAZ Buenaventura 1995: Linguistic expressions of Asian basic cultural ethics. Lecture given at the Institute of Asian Cultural Studies, International Christian University, Tokyo, Japan

Naylor, Paz Buenaventura 1999: Nominal syntax in verbal predications. Paper presented at the Linguistiche Kolloquium, Johanes Gutenburg-University of Mainz.

NAYloR, PAZ BuENAVENTURA 2001: Nominal syntax in verbal predications: Implications for Austronesian typology. Paper presented at the International Symposium on Malay and Indonesian Studies, Max Planck Institute, Leipzig.

Naylor, Paz Buenaventura 2005: On the stative predicate: Tagalog "existentials" revisited, in: LiaO, HsiU-CHUAN \& RuBino,CARL (eds.), Current issues in Philippine linguistics and anthropology: Parangal kay Lawrence A. Reid. Manila: The Linguistic Society of the Philippines and SIL Philippines, 419-435.

Payne, Thomas E. 1994: The pragmatics of voice in a Philippine language: Actor-focus and goal-focus in Cebuano narrative, in: Givón, TALmY (ed.), Voice and inversion, Typological Studies in Language - vol. 28. Amsterdam and Philadelphia: John Benjamins Publishing Company, 317-364.

REID, LAWRENCE A. 1963: The phonology of Central Bontoc. Journal of the Polynesian Society 72, 21-26.

REID, LAWRENCE A. 1965: Bontoc clause structure. MA thesis, University of Hawai i. 
REID, LAWRENCE A. 1970: Central Bontoc: Sentence, paragraph and discourse. Summer Institute of Linguistics Publications in Linguistics and Related Fields Publications No. 27. Norman: University of Oklahoma Press.

ReID, Lawrence A. 1976: Bontok-English dictionary, with English-Bontok finder list. Pacific Linguistics C-36. Canberra: Australian National University.

Reid, Lawrence A. 1992: Guinaang Bontok texts. Study of Languages and Cultures of Asia and Africa Monograph Series. Tokyo: Tokyo University of Foreign Studies.

REID, LAWRENCE A. 2002: Morphosyntactic evidence for the position of Chamorro in the Austronesian language family, in: Bauer, RoBert (ed.), Collected papers on Southeast Asian and Pacific languages. Canberra: Pacific Linguistics, 63-94.

REID, LAWRENCE A. 2005: A cross-generational view of contact-related phenomena in a Philippine language: Phonology, in: Quakenbush, Steve \& DayAg, Danilo (eds.), Sociolinguistics and Language Education in the Philippines and Beyond: Festschrift in honor of Ma. Lourdes S. Bautista. Manila: Linguistic Society of the Philippines and the Summer Institute of Linguistics.

REID, LAWRENCE A. 2006: On the origin of Philippine vowel grades. Oceanic Linguistics 45.22, 457-472.

Reid, LaWrence A. \& LiaO, Hsiu-Chuan 2004: A brief syntactic typology of Philippine languages. Language and Linguistics 5.2, 433-490.

Ross, MALCOLM D. 1995: Reconstructing Proto-Austronesian verbal morphology: Evidence from Taiwan, in: LI, PAUL Jen-Kuei, Tsang, Cheng-Hwa, Huang, Ying-Kuei, Ho, Dah-An \& Tseng, Chiu-Yu (eds.), Austronesian Studies relating to Taiwan. Taipei: Academia Sinica, 727-791.

Ross, MALCOLM D. 2002: The history and transitivity of western Austronesian voice and voice-marking. in: Wouk, FAY \& Ross, MalCOLM, The history and typology of western Austronesian voice systems. Canberra: Pacific Linguistics, 17-62.

ShiBATANi, MASAYOSHI. 1985: Passives and related constructions: A prototype analysis. Language 61.4, 821-848.

Starosta, Stanley, PaWley, Andrew K. \& Reid, Lawrence A. 1982: The evolution of focus in Austronesian, in: Wurm, Stephen A. \& CARrington, Lois (eds.), Papers from the Third International Conference on Austronesian Linguistics - vol. 2: Tracking the Travelers. Canberra: Pacific Linguistics, 145-170.

TANANGKingsing, Michael \& Huang, Shuanfan 2007: Cebuano passives revisited. Oceanic Linguistics 46.2, 554584.

Topping, Donald M. 1973: Chamorro Reference Grammar. Honolulu: The University of Hawai'i Press

TUUK, H.N. VAN DER 1971 [1864-67]: A grammar of Toba Batak. The Hague: Nijhoff.

WolfF, John U. 1973: Verbal inflection in Proto-Austronesian, in: GonZAlEz, AndREw (ed.), Parangal Kay Cecilio Lopez: Essays in honor of Cecilio Lopez on his seventy-fifth birthday. Quezon City: Linguistic Society of the Philippines, 71-91.

WolfF, John U. 1979: Verbal morphology and verbal sentences in Proto-Austronesian, in: NAYLOR, PAZ Buenaventura (ed.), Austronesian Studies: Papers from the Second Eastern Conference on Austronesian languages. Ann Arbor: Center for South and Southeast Asian Studies, the University of Michigan, 153-167.

WolfF, John U. 1996: The development of the passive verbs with pronominal prefix in Western Austronesian languages, in: NOTHOFER, BERND (ed.), Reconstruction, classification, description: Festschrift in honor of Isidore Dyen. Hamburg: Abera-Verl, 15-40. 


\section{APPENDIX}

Guina-ang Bontok examples corresponding to the same numbers in the body of this paper as they would have been analyzed by SDL.

(3) om-áli-ka=d Fontok si wákas. INTR-come-2SG $=\mathrm{P}_{\mathrm{LOC}}$ Bontok $\mathrm{P}_{\mathrm{TIME}}$ next.day 'Come to Bontoc tomorrow.'

(4) om-ára-ka=s fótog. TR-get-2sG $=\mathrm{P}_{\mathrm{ACC}}$ pig

'Get a/some pigs.'

(5) ará-e-m nan fótog. get-TR-2sG [ART pig] $]_{\mathrm{ACC}}$ 'Get the pig.'

(6) charos-a-m nan áfong. clean-TR-2SG [ART house $]_{\mathrm{ACC}}$ 'Clean the house.'

(7) iy-áli-m nan fótog. TR-bring-2SG [ART pig $]_{\mathrm{ACC}}$ 'Bring the pig.'

(8) na-ára nan fótog. PRET.PASS-get [ART pig] ${ }_{\text {NOM }}$ 'The pig was gotten.'

(9) na-charos-an nan áfong. PRET.PASS-clean-TR [ART house $]_{\text {NOM }}$ 'The house was cleaned.'

(10) na-iy-áli nan fótog. PRET.PASS-TR-Come $\left[\begin{array}{ll}\text { ART } & \text { pig }\end{array}\right]_{\mathrm{NOM}}$ 'The pig was brought.'

LAWRENCE A. REID 5-1-1-1701 Nyoidani Minoo-shi

Osaka 562-0011

JAPAN

reid@hawaii.edu
(11) in-m-éy-ak ad Fontok. PRET-INTR-go-1SG $\mathrm{P}_{\text {LOC }}$ Bontoc 'I went to Bontoc.'

(12) in-n-ey-ko nan fótog-ko. PRET-TR-go-1SG [ART pig-GEN.1SG] $]_{\mathrm{ACC}}$ 'I took my pig.'

(13) in-íla-m sak-en. PRET-see-2SG ACC.1SG 'You saw me.'

(14) sak-en, ya in-m-éy-ak. NOM.1SG COP PRET-INTR-go-1SG 'As for me, I went.'

(15) sak-en, ya in-n-ey-ko nan fótogko. NOM.1SG COP PRET-TR-go-1SG [ART pig-GEN.1SG] ACC 'As for me, I took your pig.'

(16) sak-en nan nangney si nan fótogmo. NOM.1SG ART taker $\mathrm{P}_{\mathrm{ACC}}$ ART pig-GEN.2SG 'I was the one who took your pig.' (Lit. 'The taker of your pig was me.’)

(17) iyálim nan fótog an sak-en. bring=GEN.2SG ART pig $\mathrm{P}_{\mathrm{DAT}}$ 1SG 'Bring the pig to me.' 